\title{
Degradation of histamine in tuna soup by diamine oxidase (DAO)
}

\author{
A. Naila ${ }^{1}$, S. Flint ${ }^{1}$, G. C. Fletcher ${ }^{2}$, P. J. Bremer ${ }^{3}$, \\ G. Meerdink ${ }^{4}$ \& R. H. Morton ${ }^{5}$ \\ ${ }^{1}$ Institute of Food Nutrition and Human Health, \\ Massey University, New Zealand \\ ${ }^{2}$ Food Safety \& Preservation, \\ New Zealand Institute for Plant \& Food Research Limited, New Zealand \\ ${ }^{3}$ Department of Food Science, University of Otago, New Zealand \\ ${ }^{4}$ Department of Food Manufacture and Process Technology, \\ University of Lincoln, UK \\ ${ }^{5}$ School of Sport, Massey University, New Zealand
}

\begin{abstract}
Histamine is a biogenic amine, which can cause food poisoning when present at high concentrations $(>500 \mathrm{ppm})$. In situations where the formation of histamine in food cannot be prevented through traditional methods such as refrigeration, diamine oxidase (DAO) enzyme may be a suitable method to reduce histamine concentration to safe levels. The aim of this work was to apply the enzyme to cooked tuna soup, which is one of the manufacturing steps of Rihaakuru, which often contains high levels of histamine. The DAO activity in tuna soup containing $500 \mathrm{ppm}$ of histamine, at various $\mathrm{pH}$ values (5-7) and salt concentrations (1-5\%) were examined. A central composite design (CCD) was used which contained a total of fifteen experiments. Histamine was completely degraded $(\mathrm{L}=0)$ at $\mathrm{pH} 7$ and 6.5 , and at salt level of 2 and $3 \%$. The rate of histamine reduction was optimum $(\mathrm{r}>5)$ at $\mathrm{pH} 7$ and salt level $3 \%$. To obtain complete histamine degradation and optimum rate of degradation simultaneously, salt $3 \%$ and $\mathrm{pH} 7$ was suggested.

Keywords: diamine oxidase, enzyme, histamine, tuna soup, rihaakuru, biogenic amines, maldives, fish paste, HPLC, histamine degradation.
\end{abstract}




\section{Introduction}

Histamine forms in a variety of foods such as wine, sauerkraut, cheese, fish and fish products, and fermented meats. Scombroid poisoning is a fish poisoning caused mainly by eating scombroid fish such as tuna with elevated histamine [1, 2].

Rihaakuru, a traditional dish of the Maldives that has become a delicacy, is a cooked fish paste. The raw material is tuna including skipjack (Katsuwonus pelamis), yellowfin (Thunnus albacares), big eye (Thunnus obesus), frigate (Auxis thazard) and little tunny (Euthynnus affinis) [3]. Temperature abused tuna has a high concentration of histamine [2], and Rihaakuru made with temperature abused fish can have a histamine concentration at levels which are hazardous to health (>500 ppm) (Authors unpublished data).

Histamine poisoning symptoms are similar to allergic type reactions and include facial flushing, itching, hypotension, diarrhea and nausea [1]. These symptoms can be reduced by preventing histamine formation or by degrading histamine found in foods. Histamine can be degraded by bacteria or enzymes [4]. Bacteria that have been reported as histamine degraders are: Micrococcus varians [5], Natrinema gari [6], Brevibacterium linen [7], Vergibacillus sp SK33 [8], Lactobacillus curvatus, L. sakei [9], and Staphylococcus xylosus [10]. Similarly Arthrobacter crystallopoietes KAIT-B-007 is a potential histamine degrader as the bacterium possess diamine oxidase (DAO) that degrades histamine [11]. However, for food such as Rihaakuru, which is not a fermented product, the use of bacteria may not be an effective solution to the problem, as their action will change the nature of the product. The bacteria reported as histamine degraders do not to reduce histamine completely [4-10].

The enzyme DAO has been shown to degrade histamine in a fish silage by $99 \%$ in a model system (phosphate buffer, $\mathrm{pH} 7.0$ ), and by $86 \%$ during the early stages of fermentation of fish silage [9]. The optimum activity of the enzyme has been reported to be $\mathrm{pH} 7$ and $37^{\circ} \mathrm{C}[12]$.

Response surface methodology (RSM) is a technique for optimizing processes. The performance measure is the response and the input variables are independent variables. The data can be illustrated either as a response surface: showing the relationship between the response and two independent variables, where a corresponding value exists for each independent variable; or as a contour diagram - mainly a two-dimensional graph showing contours of response for independent variables on axis systems while the remaining variables are held constant [13]. The present work employs a RSM technique based on a five-level, two-variable central composite design (CCD) with one centre point, to optimize the degradation of histamine in tuna soup, using DAO.

\section{Materials and methods}

\subsection{Materials}

Chilled yellowfin tuna (Thunnus albacares) loins (4.84 kg) were purchased from Ocean Fisheries (Palmerston North, New Zealand) and transferred to the Food 
Technology Pilot Plant freezer $\left(-18^{\circ} \mathrm{C}\right)$ of Massey University until processed. Histamine dihydrochloride was obtained from Merck Limited (Auckland, New Zealand). DAO (EC 1.4.3.6, 0.18 units $/ \mathrm{mg}$ ) from porcine liver was obtained from Sigma-Adrich (St. Louis, USA). Other chemicals for this work were obtained from Sigma-Aldrich (St. Louis, USA).

\subsection{Preparation of tuna soup}

Frozen yellowfin tuna was thawed overnight at $4^{\circ} \mathrm{C}$, cut into approximately $8 \mathrm{~cm}$ cubes and washed with potable water. The tuna cubes were added to boiling salted (1\%) water and boiled for 45 min while continuously removing the scum. The cooked tuna cubes were removed, the soup was filtered using cheese cloth and sterilized by UHT treatment $\left(143^{\circ} \mathrm{C}\right.$ for $\left.10 \mathrm{~s}\right)$. The UHT treated soup was transferred aseptically into glass bottles and kept at $4^{\circ} \mathrm{C}$ until use.

\subsection{DAO experiment on tuna soup}

The DAO experiment was based on the method of Dapkevicius et al. [9]. Tuna soup $(60 \mathrm{ml})$ was transferred into $100 \mathrm{ml}$ glass bottles and the salt level adjusted to $3 \%$ (sodium chloride) and mixed for $30 \mathrm{~s}$ before $30 \mathrm{ml}$ was added to two $50 \mathrm{ml}$ glass bottles. Histamine dihydrochloride $(500 \mathrm{ppm})$ was dissolved into one bottle of soup and DAO was dissolved $(0.5631 \mathrm{~g} / 60 \mathrm{ml}$; or 2,534 , units/L) into the other.

The soup bottles with histamine and DAO were incubated at $37^{\circ} \mathrm{C}$ for about 15 minutes, to bring the solution temperature to $37^{\circ} \mathrm{C}$. To 21 number of centrifuge tubes was added soup containing DAO $(1 \mathrm{ml})$ soup containing histamine $(1 \mathrm{ml})$. The $0 \mathrm{~h}$ samples were immediately mixed using a vortex mixer, and boiled in a boiling water bath for $30 \mathrm{~min}$, to inactivate the enzyme. The remaining samples were divided as per sampling time into plastic beakers with the sampling time labeled. The beakers were incubated at $37^{\circ} \mathrm{C}$ in a thermostat controlled shaker incubator at $100 \mathrm{rpm}$ (Model Amper Chart Multitron II, Infors HT, Total Lab Systems Ltd, Christchurch, New Zealand). Sampling was carried out after $0,0.5,1,3,5$ and $10 \mathrm{~h}$ with the enzyme being inactivated as described above. Control samples contained $2 \mathrm{ml}$ of soup containing histamine. After inactivation all samples were stored at $-80^{\circ} \mathrm{C}$ until analysis.

\subsection{Histamine analysis}

Samples stored at $-80^{\circ} \mathrm{C}$ were thawed at $4{ }^{\circ} \mathrm{C}$ overnight. Histamine analysis followed the methods of Hwang et al. [14], and Kung et al. [15], with a few modifications. A series of histamine standard solutions $(0-500 \mathrm{ppm})$ were prepared to obtain a standard curve. Histamine standard solutions $(2 \mathrm{ml})$ and each sample were combined with $1 \mathrm{ml}$ of sodium hydroxide $(2 \mathrm{M})$ and $10 \mu \mathrm{l}$ of benzoyl chloride. The solution was mixed using a flask shaker at maximum speed (Griffin flask shaker, Kumar Group, Delhi, India) for $30 \mathrm{~s}$ and placed in a $30^{\circ} \mathrm{C}$ incubator for $40 \mathrm{~min}$, for benzoylation. Benzoylation was stopped by adding $2 \mathrm{ml}$ of saturated sodium chloride and for histamine extraction $3 \mathrm{ml}$ 
diethyl ether was added, and extracted in the flask shaker at maximum speed for $5 \mathrm{~min}$. The extracted samples were centrifuged (4400 rpm for $15 \mathrm{~min}$ ) (Eppendorf Centrifuge 5702, Bio-Strategy Ltd, Auckland, New Zealand), and 2 $\mathrm{ml}$ of the upper organic layer was transferred into $15 \mathrm{ml}$ centrifuge tubes and evaporated to dryness in a stream of nitrogen. The residue was dissolved in 1.5 $\mathrm{ml}$ of methanol (HPLC grade) by mixing for $30 \mathrm{~s}$, in the flask shaker, at maximum speed, and then centrifuged for $5 \mathrm{~min}$ at $4400 \mathrm{rpm}$. The dissolved residue was filtered through a nylon membrane filter $(0.2 \mathrm{um}$, Startorium Stedim Biotech, Germany) into HPLC vials.

Histamine was analyzed by high performance liquid chromatography that consisted of the UV/VIS detector (UVD340U), thermostatted column compartment TCC-100, ASI-100 automated sample injector, P680 HPLC pump (Dionex, Dionex Pty Ltd ,New Zealand) and a LiChrospher 100 RP-18 reversedphase column ( 5 um, 125x $4.6 \mathrm{~mm}$, Merck, Ltd., New Zealand). The gradient elution program was set at a flow rate of $0.8 \mathrm{ml} / \mathrm{min}$ and the column oven temperature was set at $25^{\circ} \mathrm{C}$, throughout the analysis. The gradient program started at 50:50 (methanol/water) for $0.5 \mathrm{~min}$, linearly increasing to $85: 15$ for the next $6.5 \mathrm{~min}$, held constant at $85: 15$ for $5 \mathrm{~min}$ and decreased back to 50:50 over the next $2 \mathrm{~min}$. The volume injected was $20 \mu \mathrm{l}$ and monitored at a $254 \mathrm{~nm}$. Each sample was run for $28 \mathrm{~min}$.

\subsection{Statistical analysis}

A standard 2-factor (salt and $\mathrm{pH}$ ) 15-run central composite design (CCD) was employed to determine the optimum conditions, for DAO degradation of histamine in tuna soup (table 1).

The target optimizations were rate $(\mathrm{r}=$ exponential rate constants for the decline in $\%$ over time), and asymptote ( $\mathrm{L}=$ ultimate limits to the decline in $\%)$ of the reaction. Initially exponential models were fitted over time to each of the 15 runs, from which the parameters a (histamine amplitude in \%,), L, and r, were determined, using nonlinear regression analysis. The exponential model was developed using eqn (1);

$$
\mathrm{Y}=\mathrm{L}+\mathrm{a}^{*} \mathrm{e}^{\left(-\mathrm{r}^{*}\right)}
$$

where $\mathrm{L}=$ ultimate limits to the decline in $\%, \mathrm{a}=$ initial histamine amplitude in $\%, r=$ exponential rate constants for the decline in $\%$ over time, and $t=$ time. The $\mathrm{L}$ value was constrained; $\mathrm{L} \geq 0$.

Then RSM models were developed with salt (y) and $\mathrm{pH}(\mathrm{x})$ as independent variables, and $\mathrm{L}$ and $\mathrm{r}$ the dependent variables using regression. 
Table 1: $\quad$ Central composite design (2factors, $\mathrm{pH}$, salt).

\begin{tabular}{|c|c|c|}
\hline No. of exp. & $\mathrm{pH}$ & Salt \\
\hline 1 & 5.5 & 2 \\
\hline 2 & 6.5 & 2 \\
\hline 3 & 5.5 & 4 \\
\hline 4 & 6.5 & 4 \\
\hline 5 & 5.5 & 2 \\
\hline 6 & 6.5 & 2 \\
\hline 7 & 5.5 & 4 \\
\hline 8 & 6.5 & 4 \\
\hline 9 & 6 & 3 \\
\hline 10 & 5 & 3 \\
\hline 11 & 7 & 3 \\
\hline 12 & 6 & 1 \\
\hline 13 & 6 & 3 \\
\hline 14 & 6 & 3 \\
\hline 15 & 6 & \\
\hline & & \\
\hline
\end{tabular}

Analysis of variance (ANOVA) was used to test the significance of the regression models and their coefficients. The data analysis was performed using Minitab statistical software (Version 15, Minitab Private Ltd, Sydney NSW, Australia). A backward elimination method was utilized for the RSM fits. Significance was accepted for $\mathrm{P}<0.05$. Contour diagrams were plotted for $\mathrm{L}$ and $\mathrm{r}$ with the factors of $\mathrm{pH}$ and salt.

\section{Results and discussion}

\subsection{DAO ability to degrade histamine in tuna soup}

The exponential models fitted over time to each of the 15 runs, goodness of fit $\left(\mathrm{R}^{2}\right)$ were between 0.8-0.998 indicating good fits for observed data. The regression models for observed, and predicted fitted values for $\mathrm{L}$ and $\mathrm{r}$ are presented in table 2 .

The developed RSM models with salt $(\mathrm{y})$ and $\mathrm{pH}(\mathrm{x})$ as independent variables, and L and $r$ the dependent variables, yielded eqns (2) and (3) (table 3):

$$
\begin{gathered}
\mathrm{L}=72.12-12.58 \mathrm{x}+1.08 \mathrm{y}^{2} \\
\mathrm{r}=7.14-2.28 \mathrm{x}+0.20 \mathrm{x}^{2}+0.41 \mathrm{y}+0.07 \mathrm{y}^{2}
\end{gathered}
$$

where $\mathrm{L}=$ ultimate limits to the decline in $\%, \mathrm{x}=\mathrm{pH}, \mathrm{y}=$ salt in $\%, \mathrm{R}=$ exponential rate constants for the decline in $\%$ over time. 
Table 2: Comparison of the observed rate (r) and percentage (L) of histamine degraded by the DAO enzyme with prediction using regression models for $\mathrm{L}$ and $\mathrm{r}$.

\begin{tabular}{|c|c|c|c|c|c|c|c|c|}
\hline $\mathrm{x}$ & $\mathrm{x} 2$ & $\mathrm{y}$ & $\mathrm{y} 2$ & $\mathrm{xy}$ & $\mathrm{r}$ & $\mathrm{r}-$ fit & L & L-fit \\
\hline 5.5 & 30.25 & 2 & 4 & 11 & 0.21 & 0.20 & 0 & 7.27 \\
\hline 6.5 & 42.25 & 2 & 4 & 13 & 0.40 & 0.36 & 0 & -5.31 \\
\hline 5.5 & 30.25 & 4 & 16 & 22 & 0.12 & 0.21 & 19.52 & 20.28 \\
\hline 6.5 & 42.25 & 4 & 16 & 26 & 0.19 & 0.37 & 0 & 7.70 \\
\hline 5.5 & 30.25 & 2 & 4 & 11 & 0.16 & 0.20 & 0 & 7.27 \\
\hline 6.5 & 42.25 & 2 & 4 & 13 & 0.47 & 0.36 & 0 & -5.31 \\
\hline 5.5 & 30.25 & 4 & 16 & 22 & 0.12 & 0.21 & 3.85 & 20.28 \\
\hline 6.5 & 42.25 & 4 & 16 & 26 & 0.42 & 0.367 & 0 & 7.70 \\
\hline 6 & 36 & 3 & 9 & 18 & 0.20 & 0.17 & 13.49 & 6.40 \\
\hline 5 & 25 & 3 & 9 & 15 & 0.28 & 0.21 & 38.63 & 18.98 \\
\hline 7 & 49 & 3 & 9 & 21 & 0.46 & 0.53 & 0 & -6.18 \\
\hline 6 & 36 & 1 & 1 & 6 & 0.34 & 0.44 & 0 & -2.27 \\
\hline 6 & 36 & 5 & 25 & 30 & 0.55 & 0.45 & 37.91 & 23.75 \\
\hline 6 & 36 & 3 & 9 & 18 & 0.15 & 0.17 & 0 & 6.40 \\
\hline 6 & 36 & 3 & 9 & 18 & 0.16 & 0.17 & 0 & 6.40 \\
\hline
\end{tabular}

Table 3: $\quad$ Model coefficients.

\begin{tabular}{|c|c|c|c|c|}
\hline $\begin{array}{c}\text { Dependent } \\
\text { variable }\end{array}$ & & $\mathrm{t}$ & Sig & coefficients \\
\hline \multirow[t]{5}{*}{$r$} & constant & 2.59 & 0.03 & 7.14 \\
\hline & $\mathrm{pH}(\mathrm{x})$ & -2.43 & 0.04 & -2.28 \\
\hline & salt (y) & -3.22 & 0.01 & -0.41 \\
\hline & $\mathrm{pH} \times \mathrm{pH}\left(\mathrm{x}^{2}\right)$ & 2.45 & 0.04 & 0.20 \\
\hline & Salt x Salt $\left(\mathrm{y}^{2}\right)$ & 3.29 & 0.01 & 0.07 \\
\hline \multirow[t]{3}{*}{$\mathrm{L}$} & constant & 2.27 & 0.043 & 72.12 \\
\hline & $\mathrm{pH}(\mathrm{x})$ & -2.41 & 0.033 & -12.58 \\
\hline & Salt $x$ Salt $\left(Y^{2}\right)$ & 2.54 & 0.026 & 1.08 \\
\hline
\end{tabular}

The coefficient of determination $(\mathrm{R})$ of the dependent variables, $\mathrm{L}$ and $\mathrm{r}$, was 0.71 and 0.83 , respectively (table 4 ), which indicates that the model is suitable to represent the real relationships among the selected parameter ranges for $\mathrm{pH}$ and salt. Moreover, the correlation between salt and $\mathrm{pH}$ on the activity of DAO enzyme was strong and the prediction based on the regression line was good.

The ANOVA results showed that the model for dependent variable $\mathrm{L}$, was a significantly good as $\mathrm{F}(2,12)=6.11$ at $\mathrm{p}=0.02$ was significant $(\mathrm{P}<0.05)$. Similarly, the model for dependent variable $r$, was significantly good as $F(4,10)$ $=5.43$ at $\mathrm{p}=0.01$ was significant $(\mathrm{P}<0.05)($ table 5$)$. 
Table 4: $\quad$ Model summary.

\begin{tabular}{|c|c|c|c|c|}
\hline $\begin{array}{c}\text { Dependent } \\
\text { variable }\end{array}$ & $\mathrm{R}$ & $\mathrm{R}$ Square & $\begin{array}{c}\text { Adjusted R } \\
\text { Square }\end{array}$ & $\begin{array}{c}\text { Std. Error of } \\
\text { the Estimate }\end{array}$ \\
\hline $\mathrm{L}$ & $0.71^{\mathrm{a}}$ & 0.50 & 0.42 & 10.46 \\
\hline $\mathrm{r}$ & $0.83^{\mathrm{b}}$ & 0.69 & 0.56 & 0.10 \\
\hline
\end{tabular}

${ }^{a}$ Predictors (Constant), $\mathrm{Y}^{2}, \mathrm{X}(\mathrm{pH})$

${ }^{\mathrm{b}}$ Predictors (Constant), $\mathrm{X}(\mathrm{pH}), \mathrm{Y}^{2}, \mathrm{Y}$ (salt), $\mathrm{X}^{2}$

Table 5: $\quad$ ANOVA.

\begin{tabular}{|c|c|c|c|c|c|c|}
\hline $\begin{array}{c}\text { Dependent } \\
\text { variables }\end{array}$ & & $\begin{array}{c}\text { Sum of } \\
\text { Squares }\end{array}$ & df & $\begin{array}{c}\text { Mean } \\
\text { Square }\end{array}$ & F & Sig. \\
\hline \multirow{2}{*}{$\mathrm{L}$} & Regression & 1336.65 & 2 & 668.32 & 6.11 & $0.015^{\mathrm{a}}$ \\
\cline { 2 - 8 } & Residual & 1313.54 & 12 & 109.46 & & \\
\cline { 2 - 8 } & Total & 2650.19 & 14 & & & \\
\hline \multirow{2}{*}{$\mathrm{r}$} & Regression & 0.20 & 4 & 0.05 & 5.43 & $0.014^{\mathrm{b}}$ \\
\cline { 2 - 8 } & Residual & 0.09 & 10 & 0.009 & & \\
\cline { 2 - 8 } & Total & 0.29 & 14 & & & \\
\hline
\end{tabular}

apredictors: (Constant), $\mathrm{Y}^{2}, \mathrm{XpH}$

${ }^{b}$ Predictors: (Constant), XpH, Y ${ }^{2}$, Ysalt, $\mathrm{X}^{2}$

The contour diagram for dependent variable r-fit against salt (y-axis) and $\mathrm{pH}$ (x-axis) of DAO activity in tuna soup is shown in fig. 1.

Contour diagram

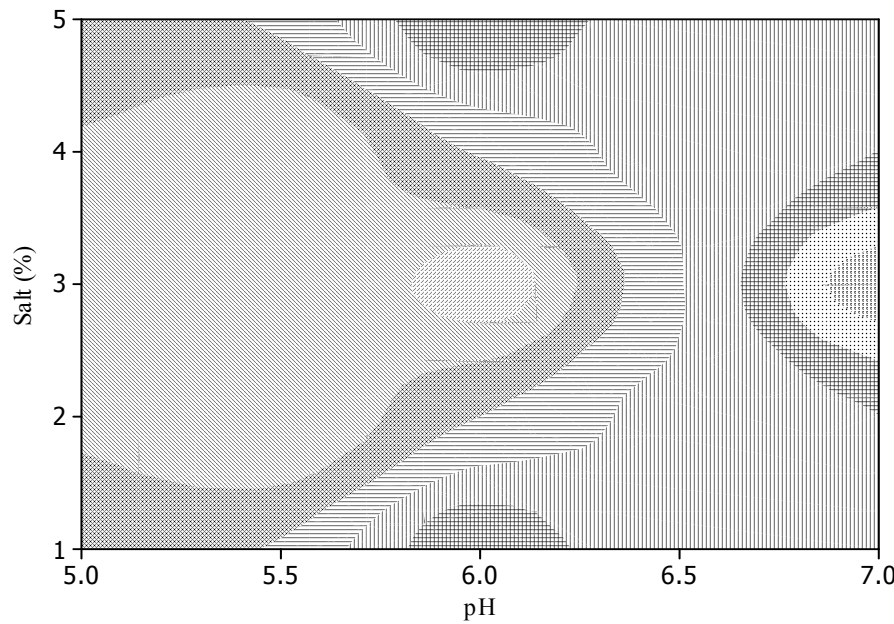

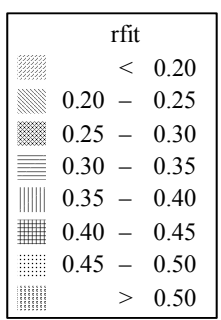

$>0.50$

Figure 1: Interaction between $\mathrm{pH}$ and salt concentration (\%) on rate (r-fit) of histamine degradation by DAO in tuna soup. 
Of the contour diagram areas, rate of histamine degradation, by DAO, was weakest between $\mathrm{pH} 5$ to approximately 6.35 and salt range of about 1.85 to 4.2 $\%(\mathrm{R}<0.2$ and between $0.2-0.25)$, where $\mathrm{pH} 6$ and salt $3 \%$ being the area the rate of the reaction was slowest. The acceptable area in the contour diagram may be considered at $\mathrm{R} \geq 0.3$ which is approximately between $\mathrm{pH} 6.35-7$, and salt 1$5 \%$. Similarly, the $\mathrm{R}$ value is greater than 0.3 at $\mathrm{pH}$ between $5-7$ and salt approximately below $1.5 \%$, and $\mathrm{pH}$ between $5-7$ and salt above $4.5 \%$. Of the experimented regions, $\mathrm{pH}$ approximately between 6.8 and 7 , and salt approximately between 2.8 to $3.2 \%$, provide the maximum region for $r$ value $>$ 0.5 , where $\mathrm{pH} 7$ and salt $3 \%$ being the optimum. Although the maximum rate of histamine degradation was obtained at $\mathrm{pH} 7$ and salt $3 \%$, the average natural condition of the soup fall between $\mathrm{pH} 5.5$ and 6.5 and salt between 1 and $3 \%$, even then, the acceptable region of $\mathrm{pH}$ and salt conditions is covered, as the DAO activity is at the acceptable range. The r-fit model has shown that the rate of the enzyme activity reached maximum up to 0.5 in tuna soup, within the experimental region; may be due to the interaction of enzyme with the tuna soup matrix, thus the rate of the reaction could not elevate further.

A contour diagram of dependent variable L-fit against salt (y-axis) and $\mathrm{pH}(\mathrm{x}-$ axis) of histamine degradation by DAO in tuna soup is shown in fig. 2 .

\section{Contour diagram}

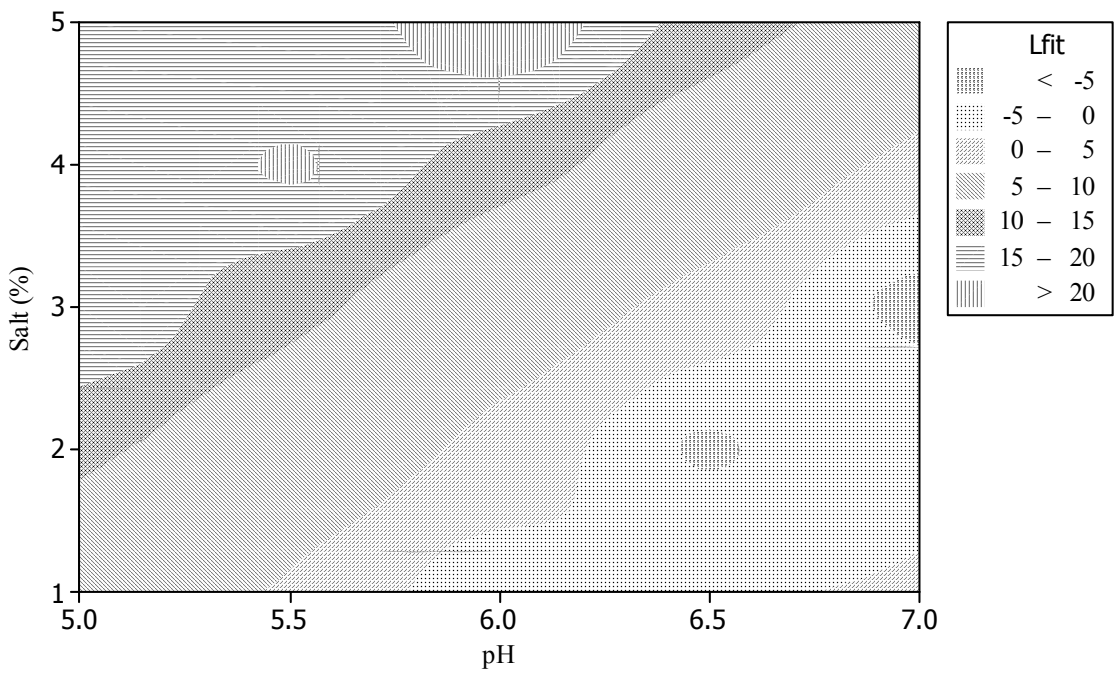

Figure 2: $\quad$ Interaction between $\mathrm{pH}$ and salt concentration (\%) on total percent (L-fit) of histamine degradation by DAO in tuna soup.

The unacceptable regions, where histamine remained between 5 and $>20 \%$, were $\mathrm{pH}$ between 5 to 6.7 and salt about 1.85 to $5 \%$, where $\mathrm{pH} 6$ and salt $5 \%$, and $\mathrm{pH} 5.5$ and salt $4 \%$ had $\mathrm{L}$ value greater than $20 \%$. The acceptable region (L: $0-5 \%$ ) in the contour diagram was like a valley that fall approximately 
between $\mathrm{pH} 5.75$ to 6.75 where salt concentration was about 1 to $1.3 \%$; and $\mathrm{pH}$ between 6.3 to 7 , where salt concentration was about 1 to $2 \%$; likewise at pH 6.5 and salt $2.5 \%$; and at $\mathrm{pH} 7$ and salt about 3.5\%. Within this acceptable region the maximum condition for complete histamine degradation was at $\mathrm{pH} 7$ and salt $3 \%$ $(\mathrm{L}=0)$. Based on the $\mathrm{L}-\mathrm{fit}$ model, most histamine $(80-100 \%)$ can be degraded by DAO within the ranges of $\mathrm{pH}$ and salt tested. However, since the natural condition of tuna soup is of $\mathrm{pH}$ between 5.5 and 6.5, and salt between 1 and $3 \%$, the maximum condition may not be applied in practice, but the stated natural condition falls within the acceptable range, where most of the histamine can be degraded by $95-100 \%$.

The most effective way of degrading histamine from tuna soup may be by merging the optimum conditions that degrade all histamine and the optimum conditions that produce the highest rate of degradation, within the experimental region. When the contour diagrams of $r$-fit and L-fit response are overlapped, the common area where the values were at optimum for both is the area of interest. In this work the common point where the maximum condition for both $\mathrm{r}$ and $\mathrm{L}$ was at $\mathrm{pH} 7$ and salt 3\%. However, the natural conditions in tuna soup had a $\mathrm{pH}$ between 5.5 and 6.5, and salt concentration between 1 and $3 \%$, thus to achieve maximum reaction, the $\mathrm{pH}$ of the soup need to be adjusted to 7 . The most practical way to approach this is to find a common area from both RSM models of $\mathrm{L}$ and $\mathrm{r}$ where the natural conditions of tuna soup exist; that is $\mathrm{pH} 5.5$ to 6.5 , and salt concentration of 1 to $3 \%$. The common optimum point within the experimental region is $\mathrm{pH} 6$ and a salt concentration of $1 \%$, where histamine can be degraded by $100 \%(\mathrm{~L}=0)$ and the rate of reaction by DAO enzyme is acceptable (r: 0.4-0.45). Once the histamine is degraded from the soup, the soup has to be further processed into Rihaakuru without any delay, as otherwise the bacteria may produce more histamine.

In conclusion, a method to degrade histamine formed in processed food has been reported. The regression model obtained, from the experimental data of histamine degradation in tuna soup using DAO, has a good correlation with that of observed and predicted variables. Under the natural $\mathrm{pH}$ (5.5-6.5) and salt concentration (1-3\%) in tuna soup degradation of histamine occurred with the process being optimal at a $\mathrm{pH}$ value of 7 and salt concentration of $3 \%$. The significance of this study is that high histamine levels in Rihaakuru can be controlled since the production of tuna soup is one of the manufacturing steps of Rihaakuru.

\section{References}

[1] Arnold, S.H. \& Brown, W.D., Histamine toxicity from fish products. Advances in Food research, ed. C.O Chichester, B.S, Schweigert, Volume 24. Academic Press: New York, pp. 113-154, 1978.

[2] Arnold, S.H., Price, R.J. \& Brown, W.D, Histamine formation by bacteria isolated from skipjack tuna Katsuwonus pelamis. Bulletin of the Japanese Society of Scientific Fisheries [Nihon Suisan Gakkai-shi], 46(8), pp. 991995, 1980. 
[3] Naila, A., Flint, S., Fletcher, G.C., Bremer, P. J. \& Meerdink, G., Chemistry and microbiology of traditional Rihaakuru (fish paste) from the Maldives. International Journal of Food Science and Nutrition, 62(2), pp. 139-147, 2011.

[4] Naila, A., Flint, S., Fletcher, G., Bremer, P. \& Meerdink, G., Control of biogenic amines in food-existing and emerging approaches. Journal of Food Science, 75(7), pp. R139-R150, 2010.

[5] Leuschner, R.G.K. \& Hammes, W.P., Tyramine degradation by Micrococci during ripening of fermented sausage. Meat Science, 49(3), pp. 289-296, 1998b.

[6] Tapingkae, W., Tanasupawat, S., Parkin, K.L., Benjakul, S. \& Visessanguan W., Degradation of histamine by extremely halophilic archaea isolated from high salt-fermented fishery products. Enzyme and Microbial Technology, 46(2), pp. 92-99, 2010.

[7] Leuschner, R.G.K. \& Hammes, W.P., Degradation of histamine and tyramine by Brevibacterium linens during surface ripening of munster cheese. Journal of Food Protection, 61(7), pp. 874-878, 1998a.

[8] Yongsawatdigul, J., Rodtong, S. \& Raksakulthai, N., Acceleration of Thai fish sauce fermentation using proteinases and bacterial starter cultures. Journal of Food Science, 72(9), pp. M382-M390, 2007.

[9] Dapkevicius, M.L.N.E, Nout, M.J.R, Rombouts, F.M., Houben, J.H. \& Wymenga, W., Biogenic amine formation and degradation by potential fish silage starter microorganisms. International Journal of Food Microbiology, 57(1-2), pp. 107-114, 2000.

[10] Mah, J.H. \& Hwang, H.J., Inhibition of biogenic amine formation in a salted and fermented anchovy by Staphylococcus xylosus as a protective culture. Food Control, 20(9), pp. 796-801, 2009.

[11] Sekiguchi, Y., Makita, H., Yamamura, A., Matsumoto, K., A thermostable histamine oxidase from Arthrobacter crystallopoietes KAIT-B-007. Journal of Bioscience and Bioengineering, 97(2), pp. 104-110, 2004.

[12] Beutling, D., Testing of starter cultures for histamine and tyramine formation. Monatshefte fuer Veterinaermedizin, 47(11), pp. 587-591, 1992.

[13] Myers, R.H., Montgomery, D.C. \& Anderson-Cook, C.M., Response surface methodology: process and product optimization using designed experiments, 3 ed., A John Wiley \& Sons, Inc.: New Jersey, pp. 704, 2009.

[14] Hwang, D.F., Chang, S.H., Shiua, C.Y. \& Chai, T.J., High-performance liquid chromatographic determination of biogenic amines in fish implicated in food poisoning. Journal of chromatography, 693(1), pp. 23-30, 1997.

[15] Kung, H.F., Chien, L.T., Liao, H.J., Lin, C.S., Liaw, E.T, Chen, W.C. \& Tsai, Y.H., Chemical characterisation and histamine-forming bacteria in salted mullet roe products. Food Chemistry, 110(2), pp. 480-485, 2008. 